\title{
ANÁLISE DO DISCURSO DE MANCHETES JORNALÍSTICAS: UMA ABORDAGEM RETÓRICO-ARGUMENTATIVA
}

\author{
Profa. Dra. Margibel A. de Oliveira \\ (Grupo de Pesquisa GERAR/USP - \\ Faculdade de Direito Damásio/IBEMEC e FATEC-SP)
}

Este estudo é parte da pesquisa desenvolvida no doutorado e tem como objetivo principal analisar as manchetes das notícias enunciadas pelo discurso jornalístico, em casos de crimes que causam grande repercussão pública, dos jornais Folha de $S P$ e $O$ Estado, divulgados online. Nesse sentido, observamos que o enunciador-jornalista antecipa, denuncia e prejulga fatos que estão ainda em sob investigação por parte dos operadores jurídicos. Por isso, sem o posicionamento de um especialista jurídico, em determinadas fases da investigação de um crime, dependendo do que está enunciado em uma manchete, tal prejulgamento se constitui em um problema, já que pode influenciar os jurados do tribunal do júri, por exemplo. Deste modo, para fundamentar a pesquisa tomamos por base: Aristóteles (384 - 322 a.C) e Mosca (2004), os quais são os principais teóricos da Retórica e Argumentação, linha de estudo principal da pesquisa. Já sobre o discurso jornalístico tomamos por base: Laje (1986; 2006), (Marcondes Filho, 1986) e Dias (1996). E para fazer a análise do discurso, ou especificamente tratar das marcas linguísticas enunciadas pelo jornalismo online nas manchetes, tomaremos por base o estudo de Charaudeau (2008; 2007) e as noções de Grácio (2012). Com base nesta fundamentação, que tem por metodologia principal a pesquisa bibliográfica, pretendemos também tratar de outro aspecto relacionado ao problema principal deste estudo, que é a falta de uma metodologia específica para analisar as manchetes das notícias selecionadas. Assim, para elaborar uma observação mais pontual sobre esse tema, foi desenvolvida uma metodologia específica de análise de discurso, a qual nomeamos de ação implícita e que pretendemos apresentar os resultados do estudo nesta comunicação. A esse respeito podemos dizer que nas manchetes enunciadas pelos jornais, quando o jornalista tem uma ação implícita, ou um propósito ao divulgar determinada informação, tal prejulgamento pode denunciar, sentenciar ou até mesmo distorcer fatos.

Palavras-chave: Análise do Discurso; Discurso Jornalístico; Retórica e Argumentação. 